\title{
Human Chorionic Gonadotropin (hCG)_An Endocrine, Regulator of Gestation and Cancer
}

\author{
Helene Heidegger and Udo Jeschke * (D) \\ Department of Obsterics and Gynecology, University Hospital, LMU Munich, 81377 Munich, Germany; \\ Helene.heidegger@med.uni-muenchen.de \\ * Correspondence: udo.jeschke@med.uni-muenchen.de; Tel.: +49-89-4400-74775
}

Received: 19 April 2018; Accepted: 17 May 2018; Published: 17 May 2018

Human Chorionic Gonadotropin (hCG) is a heterodimeric glycoprotein composed of two subunits [1]. This important and very complex molecule, that exists in different molecular forms, is implicated in all major reproductive and developmental processes in humans [1,2]. Although the title implies that hCG is an endocrine regulator, we are aware that hCG actions during pregnancy (except luteal regulation) and in cancers are largely paracrine and/or autocrine in nature. In the last years, the significance and the importance of hCG have really expanded, and many studies suggest an important role of this glycoprotein in the field of pregnancy.

hCG is secreted by the syncytiotrophoblast which originates from fused and differentiated cytotrophoblast cells [3,4]. For a long time, the main known role of hCG was the promotion of progesterone secretion by the corpus luteum in early pregnancy, acting via the hCG/LH (luteinizing hormone) receptor. However, more recently, many other functions of hCG, not only in the placenta but also in the myometrium, the uterus, and the fetus, have been described [5-7].

In addition, the LH/hCG receptor is also expressed on granulosa cells. Casarini et al. have reported that the signaling pathways of hCG and LH do not completely overlap, and this fact may have implications for hCG use in assisted reproductive techniques (ART) [8]. Hershko Klement et al. described that a gonadotropin-releasing hormone $(\mathrm{GnRH})$ agonist, initially presented as a substitute for hCG, has led to a new era of administering a GnRH agonist followed by hCG triggering [9].

hCG promotes angiogenesis and vascular genesis in the uterine vasculature during pregnancy [10,11], whereas its role in placental growth and development is incontrovertible. The hCG/LH receptor was also found in fetal organs, and thus it is suggested that hCG plays an important role in organ growth and differentiation in the fetus [12-14]. A function for hCG in umbilical cord growth and development has also been reported in the literature [15]. Many additional different immunomodulatory effects of hCG are described [16-18].

Schumacher et al. found that hCG determines fetal fate by regulating maternal innate and adaptive immune responses, allowing the acceptance of the foreign fetal antigens [19]. Environmental pollution can disturb hCG function during pregnancy. Paulescu et al. showed that prenatal exposure to selected endocrine-disrupting chemicals like Bisphenol A can have a deleterious impact on the fetus and long-lasting consequences also in adult life [2].

Some new data have shown a function of hCG in the implantation process [20,21]. Makrigiannakis et al. showed that hCG is one of the key molecules during the process of implantation. hCG effectively modulates several metabolic pathways within the decidua, contributing to endometrial receptivity [22]. In addition, the hCG/LH receptor has also been identified in adults women's brain, a finding that could explain the hyperemesis gravidarum during pregnancy [23].

The expression of hCG is observed in several types of malignancies, including prostate cancer [24], colorectal cancer [25], lung adenocarcinoma [26], and different gynecological cancers, such as endometrial adenocarcinoma, breast cancer [27], cervical carcinoma [28], and ovarian cancer [29], 
and is associated with especially poorly differentiated and high-grade tumors [30]. Human chorionic gonadotrophin may be also a possible mediator of leiomyoma growth during pregnancy [31].

Finally, Theofanakis et al. showed that hCG could have a potential role as an anti-rejection agent in solid organ transplantation [32].

In summary, hCG is a multifaceted hormone with a very wide range of actions. In this Special Issue, "hCG-An Endocrine, Regulator of Gestation and Cancer" we have tried to highlight the different functional aspects of hCG and give a promising insight into different pathophysiological aspects, clinical applications, and therapeutic options related to hCG.

Conflicts of Interest: The authors declare no conflict of interest.

\section{References}

1. Lund, H.; Paus, E.; Berger, P.; Stenman, U.H.; Torcellini, T.; Halvorsen, T.G.; Reubsaet, L. Epitope analysis and detection of human chorionic gonadotropin (hCG) variants by monoclonal antibodies and mass spectrometry. Tumour Biol. 2014, 35, 1013-1022. [CrossRef] [PubMed]

2. Paulesu, L.; Rao, C.V.; Ietta, F.; Pietropolli, A.; Ticconi, C. hCG and its disruption by environmental contaminants during human pregnancy. Int. J. Mol. Sci. 2018, 19, 914. [CrossRef] [PubMed]

3. Choi, J; Smitz, J. Luteinizing hormone and human chorionic gonadotropin: Origins of difference. Mol. Cell. Endocrinol. 2014, 383, 203-213. [CrossRef] [PubMed]

4. Nwabuobi, C.; Arlier, S.; Schatz, F.; Guzeloglu-Kayisli, O.; Lockwood, C.J.; Kayisli, U.A. hCG: Biological functions and clinical applications. Int. J. Mol. Sci. 2017, 18, 2037. [CrossRef] [PubMed]

5. Cole, L.A. Biological functions of hCG and hCG-related molecules. Reprod. Biol. Endocrinol. 2010, 8, 102. [CrossRef] [PubMed]

6. Guibourdenche, J.; Fournier, T.; Malassine, A.; Evain-Brion, D. Development and hormonal functions of the human placenta. Folia Histochem. Cytobiol. 2009, 47, S35-S40. [CrossRef] [PubMed]

7. Cole, L.A. Hyperglycosylated hCG, a review. Placenta 2010, 31, 653-664. [CrossRef] [PubMed]

8. Casarini, L.; Riccetti, L.; De Pascali, F.; Gilioli, L.; Marino, M.; Vecchi, E.; Morini, D.; Nicoli, A.; La Sala, G.B.; Simoni, M. Estrogen modulates specific life and death signals induced by LH and hCG in human primary granulosa cells in vitro. Int. J. Mol. Sci. 2017, 18, 926. [CrossRef] [PubMed]

9. Hershko Klement, A.; Shulman, A. hCG triggering in art: An evolutionary concept. Int. J. Mol. Sci. 2017, 18, 1075. [CrossRef] [PubMed]

10. Berndt, S.; Blacher, S.; Perrier d'Hauterive, S.; Thiry, M.; Tsampalas, M.; Cruz, A.; Pequeux, C.; Lorquet, S.; Munaut, C.; Noel, A.; et al. Chorionic gonadotropin stimulation of angiogenesis and pericyte recruitment. J. Clin. Endocrinol. Metab. 2009, 94, 4567-4574. [CrossRef] [PubMed]

11. Zygmunt, M.; Herr, F.; Keller-Schoenwetter, S.; Kunzi-Rapp, K.; Munstedt, K.; Rao, C.V.; Lang, U.; Preissner, K.T. Characterization of human chorionic gonadotropin as a novel angiogenic factor. J. Clin. Endocrinol. Metab. 2002, 87, 5290-5296. [CrossRef] [PubMed]

12. De Medeiros, S.F.; Norman, R.J. Human choriogonadotrophin protein core and sugar branches heterogeneity: Basic and clinical insights. Hum. Reprod. Update 2009, 15, 69-95. [CrossRef] [PubMed]

13. Nisikori, K.; Nagoshi, K.; Shimizu, K.; Yoshida, N. Assessment of fetal growth and serum hCG titers after in vitro fertilization and embryo transfer. Int. J. Gynaecol. Obstet. 1993, 41, 147-152. [CrossRef]

14. Rotsztejn, D.; Rana, N.; Dmowski, W.P. Correlation between fetal heart rate, crown-rump length, and beta-human chorionic gonadotropin levels during the first trimester of well-timed conceptions resulting from infertility treatment. Fertil. Steril. 1993, 59, 1169-1173. [CrossRef]

15. Rao, C.V.; Li, X.; Toth, P.; Lei, Z.M.; Cook, V.D. Novel expression of functional human chorionic gonadotropin/luteinizing hormone receptor gene in human umbilical cords. J. Clin. Endocrinol. Metab. 1993, 77, 1706-1714. [PubMed]

16. Akoum, A.; Metz, C.N.; Morin, M. Marked increase in macrophage migration inhibitory factor synthesis and secretion in human endometrial cells in response to human chorionic gonadotropin hormone. J. Clin. Endocrinol. Metab. 2005, 90, 2904-2910. [CrossRef] [PubMed] 
17. Schumacher, A.; Heinze, K.; Witte, J.; Poloski, E.; Linzke, N.; Woidacki, K.; Zenclussen, A.C. Human chorionic gonadotropin as a central regulator of pregnancy immune tolerance. J. Immunol. 2013, 190, 2650-2658. [CrossRef] [PubMed]

18. Lei, Z.M.; Yang, M.; Li, X.; Takikawa, O.; Rao, C.V. Upregulation of placental indoleamine 2,3-dioxygenase by human chorionic gonadotropin. Biol. Reprod. 2007, 76, 639-644. [CrossRef] [PubMed]

19. Schumacher, A. Human chorionic gonadotropin as a pivotal endocrine immune regulator initiating and preserving fetal tolerance. Int. J. Mol. Sci. 2017, 18, 2166. [CrossRef] [PubMed]

20. Licht, P.; Fluhr, H.; Neuwinger, J.; Wallwiener, D.; Wildt, L. Is human chorionic gonadotropin directly involved in the regulation of human implantation? Mol. Cell. Endocrinol. 2007, 269, 85-92. [CrossRef] [PubMed]

21. Perrier d'Hauterive, S.; Berndt, S.; Tsampalas, M.; Charlet-Renard, C.; Dubois, M.; Bourgain, C.; Hazout, A.; Foidart, J.M.; Geenen, V. Dialogue between blastocyst hCG and endometrial LH/hCG receptor: Which role in implantation? Gynecol. Obstet. Investig. 2007, 64, 156-160. [CrossRef] [PubMed]

22. Makrigiannakis, A.; Vrekoussis, T.; Zoumakis, E.; Kalantaridou, S.N.; Jeschke, U. The role of hCG in implantation: A mini-review of molecular and clinical evidence. Int. J. Mol. Sci. 2017, 18, 1305. [CrossRef] [PubMed]

23. Lei, Z.M.; Rao, C.V.; Kornyei, J.L.; Licht, P.; Hiatt, E.S. Novel expression of human chorionic gonadotropin/luteinizing hormone receptor gene in brain. Endocrinology 1993, 132, 2262-2270. [CrossRef] [PubMed]

24. Sheaff, M.T.; Martin, J.E.; Badenoch, D.F.; Baithun, S.I. Beta hCG as a prognostic marker in adenocarcinoma of the prostate. J. Clin. Pathol. 1996, 49, 329-332. [CrossRef] [PubMed]

25. Lundin, M.; Nordling, S.; Carpelan-Holmstrom, M.; Louhimo, J.; Alfthan, H.; Stenman, U.H.; Haglund, C. A comparison of serum and tissue hCG beta as prognostic markers in colorectal cancer. Anticancer Res. 2000, 20, 4949-4951. [PubMed]

26. Wong, Y.P.; Tan, G.C.; Aziz, S.; Pongprakyun, S.; Ismail, F. Beta-human chorionic gonadotropin-secreting lung adenocarcinoma. Malays. J. Med. Sci. 2015, 22, 76-80. [PubMed]

27. Kolbl, A.C.; Schlenk, K.; Behrendt, N.; Andergassen, U. The importance of hCG in human endometrial adenocarcinoma and breast cancer. Int. J. Biol. Markers 2018, 33, 33-39. [CrossRef] [PubMed]

28. Crawford, R.A.; Iles, R.K.; Carter, P.G.; Caldwell, C.J.; Shepherd, J.H.; Chard, T. The prognostic significance of beta human chorionic gonadotrophin and its metabolites in women with cervical carcinoma. J. Clin. Pathol. 1998, 51, 685-688. [CrossRef] [PubMed]

29. Lenhard, M.; Tsvilina, A.; Schumacher, L.; Kupka, M.; Ditsch, N.; Mayr, D.; Friese, K.; Jeschke, U. Human chorionic gonadotropin and its relation to grade, stage and patient survival in ovarian cancer. BMC Cancer 2012, 12, 2. [CrossRef] [PubMed]

30. Schuler-Toprak, S.; Treeck, O.; Ortmann, O. Human chorionic gonadotropin and breast cancer. Int. J. Mol. Sci. 2017, 18, 1587. [CrossRef] [PubMed]

31. Sarais, V.; Cermisoni, G.C.; Schimberni, M.; Alteri, A.; Papaleo, E.; Somigliana, E.; Vigano, P. Human chorionic gonadotrophin as a possible mediator of leiomyoma growth during pregnancy: Molecular mechanisms. Int. J. Mol. Sci. 2017, 18, 2014. [CrossRef] [PubMed]

32. Theofanakis, C.; Drakakis, P.; Besharat, A.; Loutradis, D. Human chorionic gonadotropin: The pregnancy hormone and more. Int. J. Mol. Sci. 2017, 18, 1059. [CrossRef]

(C) 2018 by the authors. Licensee MDPI, Basel, Switzerland. This article is an open access article distributed under the terms and conditions of the Creative Commons Attribution (CC BY) license (http:/ / creativecommons.org/licenses/by/4.0/). 